\title{
Menakar Problematika Pengelolaan Zakat Di Zaman Modern
}

\author{
M. Maulana Asegaf \\ Institut Pesantren KH Abdul Chalim Mojokerto \\ Maulana.asegaf@yahoo.com
}

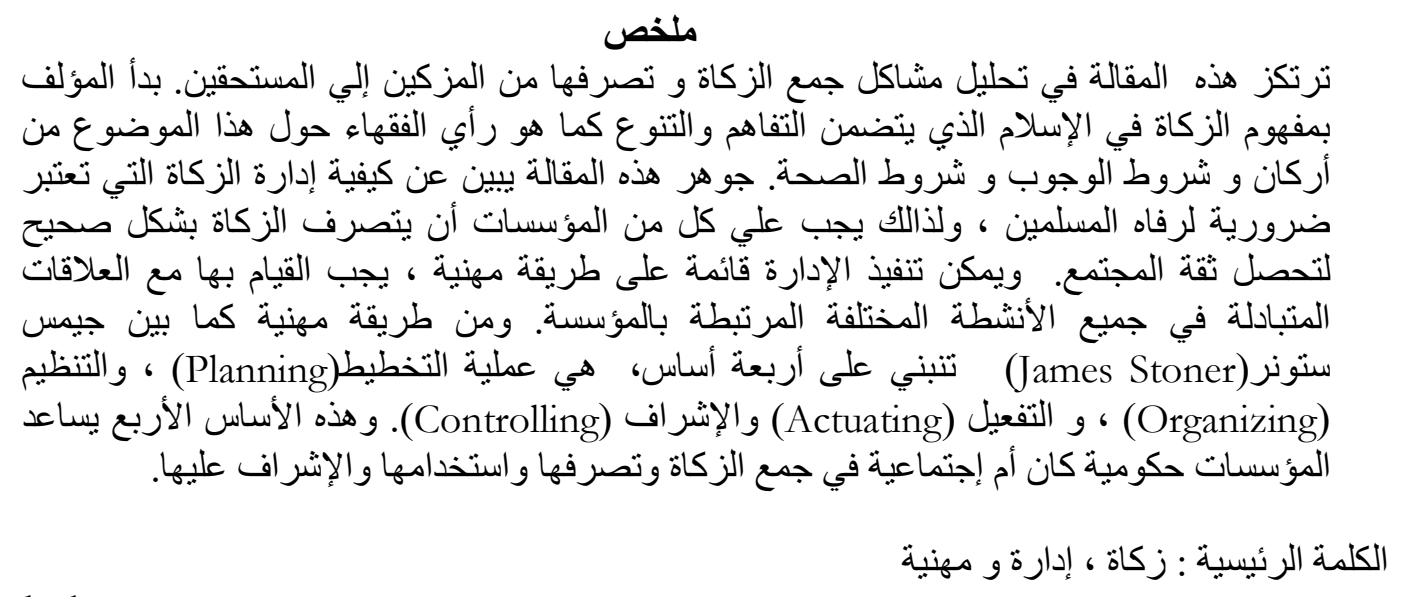

\section{Pendahuluan}

Zakat adalah ibadah yang tercakup dalam rukun Islam. kewajiban zakat harus dilaksanakan oleh para muzakki dalam hal ini adalah orang-orang yang memiliki harta lebih dari kebutuhan primer. Kemudian di salurkan kepada para mustahiq, yakni orang-yang berhak menerima zakat sesuai dengan tuntunan syara'. ${ }^{27}$

Zakat merupakan hal yang sangat penting bagi perkembangan kesejahteraan umat Islam. Sumber-sumber pokok ajaran Islam (al-Qur'an dan Hadits) telah menjelaskan bagaimana zakat harus ditata dan kelola dengan baik, terutama dengan adanya amil sebagai salah satu kelompok yang mendapatkan dan mendistribusikan zakat atas jasa profesionalitasnya dalam mengelola zakat. Namun, secara riilnya pengelolaan zakat ini sulit dipraktekkan dalam masyarkat muslim di berbagai daerah. Di antaranya ketidakpercayaan muzakki menyerahkan zakatnya kepada amil.

Namun di era modern sekarang ini pengelolaan zakat ditingkatkan sedemikian rupa, sehingga dapat dikelola secara baik. Para pengelola telah merumuskan pengelolaan zakat berbasis manajemen. Pengelolaan zakat berbasis manajemen dapat dilaksanakan dengan pikiran dasar bahwa semua aktivitas yang terkait dengan zakat harus dikerjakan dengan professional. Pengelolaan zakat secara professional, perlu dilakukan dengan saling keterkaitan antara berbagai aktivitas yang terkait dengan zakat. Dalam hal ini, keterkaitan antara sosialisasi, pengumpulan, pendistribusian atau pendayagunaan, serta pengawasan. Semua kegiatan itu harus dilakukan menjadi sebuah kegiatan secara utuh, tidak dilaksanakan secara parsial atu bergerak sendiri-sendiri. ${ }^{28}$

Dalam membangun manajemen dalam mengelola zakat dapat menggunakan teori James Stoner. Model manajemen tersebut meliputi proses perencanaan (planning), pengorganisasian (organizing), pengarahan (actuating) dan pengawasan (controlling). Keempat model Stoner ini dapat diterapkan dalam setiap aktivitas pengelolaan zakat dengan konsep sosialisasi, pengumpulan, pendayaguaan dan pengawasan. ${ }^{29}$

\section{Konsep Zakat dalam Islam}

\footnotetext{
${ }^{27}$ Rofiq, Ahmad, Fiqh Kontekstual: Dari Normatif ke Pemaknaan Sosial, (Yogyakarta: Pustaka Pelajar, 2012), 259.

${ }^{28}$ Muhammad Hasan, Manajemen Zakat: Model Pengelolaan Zakat yang Efektif, (Yogyakarta: Idea Press, 2011), 20-21.

${ }^{29}$ Ibid., 21
} 


\section{Makna Zakat}

Secara bahasa, zakat berasal dari bahasa Arab زكى - زكى - mempunyai arti berkah, tumbuh, bersih dan baik. Dalam mu'jam al-Wasith dijelaskan bahwa zakat secara bahasa adalah berkah, suci, baik, tumbuh, dan bersihnya sesuatu. ${ }^{30}$

Secara etimologi, makna-makna zakat di atas bisa terkumpul dalam ayat berikut, firmanNya:

Artinya: Ambilalh rakat dari sebagian harta mereka, dengan menyucikan mereka (QS. 9: 103)

Dalam al-Qur'an dan hadits, shadaqah juga bermakna zakat, oleh karena itu Imam al-Mawardi menyatakan: Kalimat shadaqah terkadang dimaksud adalah zakat, dan zakat yang dimaksud adalah shadaqah, dua kata yang berbeda, tetapi memiliki inti yang sama.$^{31}$ Maka, maksud ayat di atas adalah, zakat itu akan dapat menyucikan orang yang menunaikannya dan akan menambah pahalanya.

Sedangkan menurut syara', zakat adalah hisab tertentu dari mal (harta) dan sejenisnya di mana syara' mewajibkan mengeluarkannya kepada para fakir, dan sejenisnya dengan syarat-syarat khusus. ${ }^{32}$ Menurut pendapat lain, zakat adalah hak yang wajib ditunaikan dari harta. Menurut mazhab Syafi'I, zakat adalah sebuah ungkapan untuk keluarnya harta sesuai bi thariqin makhsus, dan diberikan kepada 8 kelompok yang berhak menerima zakat. Hal ini termaktub dalam firman-Nya:

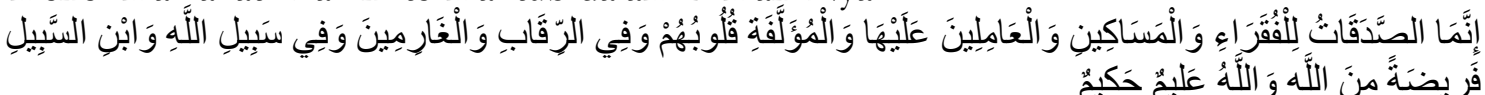

Artinya: Sesunggubnya zakat-zakat itu, hanyalah untuk orang-orang fakir, orang-orang miskin, pengurus-pengurus zakat, para mu'allaf yang dibujuk hatinya, untuk (memerdekakan) budak, orangorang yang berbutang, untuk jalan Allah dan untuk mereka yuang sedang dalam perjalanan, sebagai suatu ketetapan yang diwajibkan Allah, dan Allab Maha Mengetabui lagi Maha Bijaksana (QS. AlTaubah: 60).

Zakat dikeluarkan pada waktu yang khusus, dalam artian bahwa sempurnanya kepemilikan itu selama setahun (haul), baik harta berupa al-An'am, an-Naqdain, Urudh atTijarah, as-Tsimar wa al-Hubub, al-Ma'adin, yang semuanya wajib dizakati. Maka dapat disimpulkan secara syara', zakat adalah penunaian hak yang wajib yang terdapat dalam harta. Zakat juga dimaksudkan sebagai bagian harta tertentu dan yang diwajibkan oleh Allah untuk disalurkan kepada delapan asnaf. ${ }^{33}$

\section{Zakat dan Macamnya}

Sebagaimana telah dijelaskan di atas, bahwa zakat secara harfiah adalah bersih, meningkat, dan berkah. Sedangkan menurut istilahnya adalah mengeluarkan sebagian harta dari harta yang telah memenuhi syarat minimal (nishab) dan rentang waku satu tahun (haul) yang menjadi hak dan diberikan kepada mustahiq (penerima zakat). ${ }^{34}$

Para ulama' membagi zakat menjadi dua bagian, yaitu: Pertama, zakat fitrah, yaitu mengeluarkan 1 Sha' dari makanan pokok (yang senilai) yang bersangkutan (setiap orang Islam besar, kecil, tua, laki-laki, perempuan merdeka dan budak) diberikan kepada yang berhak menerimanya (mustahiq). Waktu pelaksanaannya sampai dengan pelaksanaan shalat 'idul Fitri, dan boleh di dahulukan (ta'jil) selama bulan ramadhan. Kedua, zakat mal.

\footnotetext{
${ }^{30}$ Gus Arifin, Dalil-Dalil dan Keutamaan Zakat, Infak dan Sedekah, (Jakarta: PT. Elex Media Komputindo, 2011 ), 4.

${ }^{31}$ Muhammad Taufiq Ridlo, Zakat Profesi dan Perusahaan, (Jakarta:Institut Manajemen Zakat, 2007$), 15$.

${ }^{32}$ Ibrahim Mustafa, al-Mu'jam al-Wasith, (Kairo: Dar al-Da'wah, tth), 395.

${ }^{33}$ Wahbah Al-Zuhayly, Fiqh al-Islamiy wa Adillatuh Vol:2 , (Damaskus: Darul Fikr, 1984), 738.

${ }^{34}$ Ahmad Rofiq, Fiqh Kontekstual: Dari Normatif ke Pemaknaan Sosial, (Yogyakarta: Pustaka Pelajar, 2012 ), 262.
} 
Zakat jenis ini meliputi al-An'am (hewan-hewan ternak), an-Naqdain (emas dan perak), Urudh atTijarah (barang dagangan), as-Tsimar wa al-Hubub (buab-buaban dan biji-bijian), al-Ma'adin( barang tambang), ar-Rikaz, barang temuan).$^{35}$

Sebagai ibadah maliyah ijtima'iyah, zakat baru diwajibkan ketika seseorang yang memiliki harta memenuhi syarat sebagai berikut: Islam, merdeka, milik sempurna, telah sampai nisab, dan telah dimiliki selama setahun (haul) untuk beberapa jenis zakat. Berikut tabel kewajiban pengeluarkan zakat bagi para muzakki:

\begin{tabular}{|c|c|c|c|c|}
\hline No & Jenis Barang & Nisab & Zakat & Keterangan \\
\hline \multirow{3}{*}{1} & Ternak unta & $\begin{array}{l}5-9 \text { ekor } \\
10-14 \text { ekor }\end{array}$ & $\begin{array}{l}1 \text { kambing } \\
2 \text { kambing }\end{array}$ & $\begin{array}{l}\text { Usia } 2 \text { tahun } \\
\text { Usia } 2 \text { tahun }\end{array}$ \\
\hline & $\begin{array}{l}\text { Ternak } \\
\text { kerbau/ } \\
\text { Sapi }\end{array}$ & $\begin{array}{l}30-39 \text { ekor } \\
40-59 \text { ekor } \\
60-69 \text { ekor }\end{array}$ & $\begin{array}{l}1 \text { kerbau } \\
1 \text { kerbau } \\
2 \text { kerbau }\end{array}$ & Usia 2 tahun \\
\hline & $\begin{array}{l}\text { Ternak } \\
\text { kambing }\end{array}$ & $\begin{array}{l}40-120 \\
\text { Ekor } \\
120-200 \\
\text { Ekor } \\
210-399 \\
\text { Ekor }\end{array}$ & $\begin{array}{l}1 \text { kambing } \\
\text { Betina } \\
2 \text { kambing } \\
\text { Betina } \\
3 \text { kambing } \\
\text { Betina }\end{array}$ & 2 tahun \\
\hline \multirow{3}{*}{2} & Emas & 20 misqal & $\begin{array}{l}2,5 \%=0,5 \\
\text { Misqal }\end{array}$ & $\begin{array}{l}20 \text { misqal= } \\
93,6 \mathrm{gr} \\
\text { di luar } \\
\text { Perhiasan } \\
\text { Wajar }\end{array}$ \\
\hline & Perak & 200 dirham & $\begin{array}{l}2,5 \%=5 \\
\text { Dirham }\end{array}$ & $\begin{array}{l}200 \text { dirham }= \\
624 \mathrm{gr}\end{array}$ \\
\hline & $\begin{array}{l}\text { Perhiasan } \\
\text { di luar } \\
\text { kewajaran }\end{array}$ & 20 misqal & $\begin{array}{l}2,5 \%=0,5 \\
\text { Misqal }\end{array}$ & \\
\hline
\end{tabular}

${ }^{35}$ Wahbah Al-Zuhayly, Fiqh al-Islamiy wa Adillatuh Vol:2, 738. 


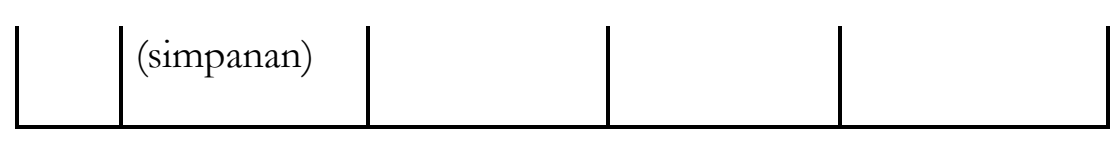

\begin{tabular}{|c|c|c|c|c|}
\hline 3 & $\begin{array}{l}\text { Makanan } \\
\text { Pokok }\end{array}$ & $\begin{array}{l}\text { Lebih dari } \\
5 \text { wasaq }= \\
780 \mathrm{~kg}\end{array}$ & $\begin{array}{l}\text { 1/10 irigasi } \\
\text { Alam } \\
1 / 20 \text { irigasi } \\
\text { Biaya }\end{array}$ & $\begin{array}{l}\text { Setiap panen } \\
1 \text { wasaq }=60 \\
\text { sha', } \\
1 \text { sha' }=2,6 \mathrm{~kg}\end{array}$ \\
\hline 4 & $\begin{array}{l}\text { Buah- } \\
\text { buahan }\end{array}$ & $\begin{array}{l}\text { Lebih dari } \\
5 \text { wasaq }= \\
200 \text { dirham }\end{array}$ & $\begin{array}{l}\text { 1/10 irigasi } \\
\text { Alam } \\
1 / 20 \text { irigasi } \\
\text { Biaya }\end{array}$ & $\begin{array}{l}\text { Setiap panen } \\
1 \text { wasaq }=60 \\
\text { sha', } \\
1 \text { sha' }=2,6 \mathrm{~kg} \\
\text { Setiap panen }\end{array}$ \\
\hline 5 & Perniagaan & $\begin{array}{l}\text { Analog } \\
\text { Dengan } \\
\text { emas 93,6 } \\
\text { Gram }\end{array}$ & $2,5 \%$ & $\begin{array}{l}1 \text { tahun } \\
\text { dr awal } \\
\text { Perhitungan }\end{array}$ \\
\hline & & & & \\
\hline
\end{tabular}

\section{Pengelolaan Zakat Berbasis Manajemen}

1. Konsep Dasar Pengelolaan Zakat

Pada dasarnya, konsep dasar pengelolaan zakat berangkat dari firman Allah dalam al-

Qur'an surat al-Taubah ayat 103, firman-Nya:

$$
\text { خذ من أمو الهم صدقة تطهر هم وتزكيهم بها وصل عليهم إن صلاتك سكن لهم و الله سميع عليم }
$$

Artinya: Ambillah zakat dari sebagian harta mereka, dengan zakat itu kamu membersibkan dan mensucikan mereka dan mendoalah untuk mereka. Sesunggubnya doa kamu itu (menjadi) ketenteraman jiwa bagi mereka. Dan Allah Maha Mendengar lagi Maha Mengetabui (QS. AlTaubah: 103).

Ayat ini dapat dipahami bahwa kata khudz (berbentuk fi'il amar) menunjukkan bahwa mengumpulkan zakat dari para muzakki oleh amil zakat hukumnya wajib. Hal ini didasarkan oleh kaidah ushul fiqih, bahwa fiil amar menunjukkan suatu perintah wajib. Maka, mengumpulkan zakat dari orang yang mengeluarkan zakat hukum wajib ain. ${ }^{36}$

Sebuah kewajiban bukanlah mudah dilaksanakan, begitu juga dalam melaksanakan kewajiban mengumpulkan zakat. Apalagi dihadapkan pada masyarakat yang mempunyai kultur dan karakter yang berbeda-beda. Oleh karena itu, mengumpulkan zakat

${ }^{36}$ Muhammad Hasan, Manajemen Zakat: Model Pengelolaan Zakat yang Efektif,), 8. 
membutuhkan persiapan dan perencanaan yang matang. Semua aktivitas dan faktor-faktor terkait dengan aktifitas tersebut mesti terencana, teroganisir, bahkan terkontrol dan dievaluasi tingkat capaiannya. Dalam konteks inilah manajemen untuk mengelola zakat sangat diperlukan agar pengelolaan itu berjalan dengan baik dan sistematis serta tepat sasaran.

Para ulama membuat formula tentang tata cara mengelola zakat dengan baik. Maka mereka mempunyai pandangan-pandangan tentang pengelolaan zakat sebagai berikut: Pertama, para ulama' sepakat bahwa yang berhak mengumpulkan zakat harta tidak bergerak dan mendistribusikannya adalah pemimpin yang ada pada suatu daerah kaum muslimin. $\mathrm{Hal}$ ini tidak boleh ditangani secara perorangan, termasuk pendistribusiannya. Hal ini dilandaskan pada dalil dari sabda Rasulullah, bahwa Rasulullah memerintahkan utusan dan para pekerjanya untuk mengumpulkan zakat dari kaum Muslimin, dan Rasulullah sendiri pulalah yang memaksa kaum muslimin agar mereka menunaikan zakatnya untuk kepentingan negegara, dan memerangi orang yang menolak untuk menunaikannya.

Kedua, para ulama' telah sepakat bahwa pengumpulan dan pendistribusian zakat pada harta bergerak, baik berupa uang maupun barang dagangan, dilakukan oleh pemimpin. Iman al-Razi ketika menafsirkan surat al-Taubah ayat 60, ia menjelaskan bahwa zakat berada di bawah pengelolaan pemimpin atau pemerintah. Dalil ini juga menunjukkan, bahwasanya Allah menjadikan setiap panitia zakat bagian dari zakat itu sendiri, yang kesemuanya ini menunjukkan atas kewajiban dalam menunaikan tugas yang dibebankan. ${ }^{37}$

Pengelolaan zakat mengharuskan adanya persiapan dan perencanaan yang matang. Semua aktifitas dan faktor-faktor terkait dengan aktifitas tersebut mesti terencana, terorganisir, bahkan terkontrol dan dievaluasi tingkat capaiannya. Hal ini diperlukan agar pengelolaan zakat dapat dilakukan secara efektif dn efisien. Dalam konteks pengelolaan zakat, tujuan zakat akan tercapai manakala zakat dikelola secara baik berdasarkan prinsipprinsip manajemen. Dengan kata lain, manajemen zakat merupakan perantara bagi tercapainya kesempurnaan pelaksanaan zakat. Oleh karena itu, dalam pengumpulan zakat mestinya didasarkan pada prinsip-prinsip manajemen. ${ }^{38}$

Di indonesia Badan Amil Zakat (BAZ) sudah terbentuk mulai pusat sampai daerah. Badan Amil Zakat Nasional (BAZNAS) merupakan badan resmi dan satu-satunya yang dibentuk oleh pemerintah berdasarkan Keputusan Presiden RI No. 8 Tahun 2001 yang memiliki tugas dan fungsi menghimpun dan menyalurkan zakat, infaq, dan sedekah (ZIS) pada tingkat nasional. Lahirnya Undang-Undang Nomor 23 Tahun 2011 tentang Pengelolaan Zakat semakin mengukuhkan peran BAZNAS sebagai lembaga yang berwenang melakukan pengelolaan zakat secara nasional. Dalam UU tersebut, BAZNAS dinyatakan sebagai lembaga pemerintah nonstruktural yang bersifat mandiri dan bertanggung jawab kepada Presiden melalui Menteri Agama. ${ }^{39}$ Atas keseriusan pemerintah menangani pengelolaan zakat, maka pada tahun 1999 pemerintah telah menerbitkan Undang-Undang No. 38 Tahun 1999 tentang pengelolaan zakat. Dalam kondisi demikian, kewajiban mengumpulkan zakat di Indonesia harus dilakukan oleh amil-amil zakat. Oleh karena itu, dapat dipahami bahwa dalam konteks ke Indonesiaan khitab ayat tersebut adalah amil zakat yang diwakili oleh BAZ. ${ }^{40}$

Sebelum dikeluarkannya peraturan pemerintah di atas, pola pengelolaan zakat di Indonesia telah dilakukan sejak belum merdeka. Ketika Indonesia merdeka gerakan kesadaran membayar zakat telah dilakukan secara lebih baik oleh elemen-elemen

\footnotetext{
${ }^{37}$ Yusuf Al-Qardhawi, Fiqh al-Zakat: Dirasah Muqaranah li Ahkamiha wa Falsafatiha fi Dhau'al-Qur'an wa al-Sunnah, Beirut: Muassasah al-Risalah, 1997), 110.

${ }^{38}$ Muhammad Hasan, Manajemen Zakat: Model Pengelolaan Zakat yang Efektif,), 9.

39 http://baznas.go.id/profil

${ }^{40}$ Muhammad Hasan, Manajemen Zakat: Model Pengelolaan Zakat yang Efektif,), 8.
} 
masyarakat. Kesadaran ini tentunya perlu diiringi dengan tindakan riil oleh segenap masyarakat untuk saling mengingatkan dan menasehati arti penting zakat bagi keselarasan hidup. Maka selayaknya pemerintah dilibatkan dalam pengelolaan zakat, baik sebagai regulator maupun fasilitator, dengan suatu kewajiban memberikan perlindungan, pembinaan, dan pelayanan kepada muzakki, lembaga zakat dan mustahiq. ${ }^{41}$

2. Sejarah Awal Pengelolaan Zakat

Menurut cacatan sejarah, zakat diwajibkan pada tahunke-2 hijriyah. Namun, para ahli Hadits memandang bahwa zakat telah diwajibkan sebelum tahun ke 9 hijriyah. Ini didasarkan atas pendapat Maulana Abdul Hasan bahwa zakat diwajibkan setelah hijrah dan dalam kurun waktu lima tahun setelahnya. Sebelumnya, zakat bersifat suka rela dan belum ada peraturan khusus atau ketentuan hukum. Peraturan mengenai pengeluaran zakati di atas muncul pada tahun ke-9 hijriah ketika dasar Islah telah kokoh, wilayah kekuasaan Islam sudah meluas, orang-orang sudah berbondong-bondong masuk Islam. ${ }^{42}$

Pada saat itulah, peraturan tentang zakat di susun. Peraturan yang disusun meliputi tatacara pengumpulan zakat, barang-barang yang diharuskan, batas-batas zakat dan tingkat presentase zakat untuk barang yang berbeda-beda. Peraturan ini muncul karena pada saat itu pengumpulan zakat bukanlah pekerjaan yang memerlukan waktu dan para pegawainya tidak diberikan gaji resmi, akan tetapi mereka memperoleh bayaran dari dana pengelolaan zakat.

Pada masa Rasulullah Saw. zakat dan ushr merupakan pendapatan utama negara. Pengeluaran untuk zakat tidak dapat dibelanjakan untuk pengeluaran umum negara. Lebih jauh lagi, zakat secara fundamental adalah pajak lokal. Dengan demikian, pemerintahan pusat berhak menerima keuntungan hanya bila terjadi surplus yang tidak dapat didistribusikan lagi kepada orang-orang yang berhak, dan ditambah kekayaan yang dikumpulkan di Madinah. ${ }^{43}$ Maka pada zaman Rasullah ini, zakat dikenakan pada hal-hal berikut:

1. Benda logam yang terbuat dari emas.

2. Benda logam yang terbuat dari perak.

3. Binatang ternak, seperti unta, sapi, domba dan kambing.

4. Berbagai ternak barang dagangan termasuk budak dan hewan.

5. Hasil pertanian termasuk buah-buahan.

6. Luqathah, harta benda yang ditinggalkan musuh.

7. Rikaz/ barang temuan.

Setelah Rasulullah wafat, Abu Bakar dimandati sebagai khalifah setelahnya. Pada pemerintahan Abu Bakar beberapa kaum muslimin menolak membayar zakat khususya kaum munafiq, kemudian beliau memerintahkan untuk memerangi mereka yang menolak. Dalam masalah pengelolaan zakat, Abu Bakar memperhatikan masalah keakuratan penghitungan zakat, sebagaimana yang beliau katakana kepada Anas (seorang amil): "Jika seorang yang harus membayar satu onta berumur setabun, sedangkan dia tidak memilikinya dan ia menawarkan untuk memberikan seekor onta betina yang berumur dua tabun. Hal tersebut dapat diterima, kolektor zakat akan mengembalikan 20 dirham atau dua kambing padanya (sebagai kelebihan pembayarannya). Abu Bakar mengambil langkah-langkah tegas untuk mengumpulkan zakat dari semua umat Islam (muzakki) termasuk Badui yang kembali memperlihatkan tandatanda pembangkangan . ${ }^{44}$

\footnotetext{
${ }^{41}$ Depag RI, Standarisasi Manajemen Zakat, (Jakarta: DirektoratJenderal Bimbingan Masyarakat Islam DirektoratPemberdayaan Zakat, 2007), 10.

${ }^{42}$ Muhammad Hasan, Manajemen Zakat: Model Pengelolaan Zakat yang Efektif,), 9.

${ }^{43}$ Ibid., 10 .

${ }^{44}$ Ibid ., 11.
} 
Pada zaman Umar bin Khattab, zakat menjadi pondasi pertama dalam membangun jaminan kemasyarakatan ataupun takaful (saling tolong menolong) dalam kehidupan yang berlaku dalam masyarakat Islam. Sebagaimana hal ini, juga menjadi bukti bahwa zakat adalah bantuan yang berkesinambungan dan terorgnisir; hingga apabila zakat tersebut tidak sampai ke tangan yang berhak menerimanya (mustahiq), maka sudah menjadi haknya untuk melaporkan. ${ }^{45}$

\section{Urgensi Pengelolaan Zakat Berbasis Manajemen}

1. Urgensi Manajemen dalam Pengeololaan Zakat

Kata manajemen dalam bahasa Arab disebut dengan istilah idarah dan tadbir. Kata idarah dalam al-Qur'an tidak ditemukan, sedangkan kata tadbir bisa ditemukan meskipun menggunakan bentuk fi'il mudhari' yaitu yudabbir. Dalam al-Qur'an menggunakan kata yudabbir sebanyak 6 kali, antara lain dalam QS. Yunus: 3 dan 31. Dalam dua ayat tersebut dijelaskan bahwa Allah lah yang mengatur semua urusan di langit dan di bumi seperti kehidupan, kematian rizki, pendengaran, dan penglihatan. Namun menganjurkan kepada manusia agar mencontoh sifat Tuhan dalam memakmurkan bumi (QS. Yunus: 61), dan sebagai khalifah, berarti manajemen berarti sesuatu yang Qur'ani, dijelaskan dalam alQur'an. Maka, pengelolaan zakat pun harus dilakukan dengan cara-cara Qur'ani pula. ${ }^{46}$

Al-Qardhawi menjelaskan bahwa terdapat beberapa syarat yang harus dipenuhi untuk dapat meraih kesuksesan dalam mengelola zakat pada zaman modern ini, khususnya apabila pengelolaan zakat ditangani oleh suatu lembaga zakat: pertama, perluasan dalam kewajiban zakat. Maksudnya, semua harta yang berkembang (al-Mal an-Nami) mempunyai tanggungan wajib zakat dan berpotensi sebagai solusi bagi penanganan kemiskinan. Kedua, mengelola zakat dari harta tetap dan tidak tetap harus transparan, bisa dikelola oleh lembaga yang telah ditunjuk oleh pemerintah. Ketiga, dalam pengelolaan zakat harus tertib administrasi yang accountable dan dikelola oleh para penanggung jawab yang professional. Keempat, di saat zakat telah dikumpulkan oleh amil (pengelola zakat), zakat harus didistribusikan secara accountable juga. ${ }^{47}$

Para ulama' berbeda pendapat mengenai tata kelola dan manajemen dalam pengelolaan zakat, meskipun demikian pengumpulan zakat berbasis manajemen merupakan suatu kebutuhan dalam masyarakat modern. Kredibilitas suatu lembaga amil zakat sangat tergantung pada kemampuannya mengelola zakat secara professional dan transparan. Sebab, selama ini para muzakki umumnya, lebih suka menyampaikan zakat secara langsung kepada mustahiq. Pembayaran zakat masih banyak dilakukan sendiri-sendiri mengikuti tradisi yang berlaku secara turun-temurun, tanpa pemahaman yang komprehensif belum dikelola secara organisatoris, pemanfaatan dan pendistribusiannya belum merata, dan belum berdaya guna dalam pemberdayaan potensinya untuk mengentaskan kemiskinan. ${ }^{48}$

Lebih lanjut Hasan menjelaskan tentang mengapa masyarakat menggunakan caracara lama, yang seharusnya mereka berpikir tentang pentingnya mengelola zakat dalam sebuah manajemen yang rapi:

1. Muzakki tidak percaya dengan pengeloaan zakat yang dilakukan amil selama ini.

2. Zakat diyakini umat Islam sebagai ibadah mahdhah, oleh sebab itu mereka akan lebih suka menyampaikan sendiri hartanya kepada para mustahik pasti sampai dan dapat langsung dimanfaatkan oleh para mustahiq. Sedangkan melalui manajemen

\footnotetext{
${ }^{45}$ Yusuf Al-Qardhawi, Spektrum Zakat: Dalam Membangun Ekonomi Kerakyatan, terj. Sari Nurulita, (Jakarta: Zikrul Media Intelektual, 2005), 57.

${ }^{46}$ Muhammad Hasan, Manajemen Zakat: Model Pengelolaan Zakat yang Efektif,), 17.

${ }^{47}$ Yusuf A1-Qardhawi, Spektrum Zakat), 59.

${ }^{48}$ Muhammad Hasan, Manajemen Zakat: Model Pengelolaan Zakat yang Efektif,), 18.
} 
zakat, muncul kekhawatiran zakat tidak bisa langung diterima oleh para mustahiqnya.

3. Muzaki lebih yakin bahwa seandainya ia menyampaikan sendiri hartanya kepada para mustahiq pasti sampai dan dapat dimanfaatkan langsung oleh para mustahiq. Sedangkan jika melalui badan amil, mereka belum yakin bahwa mustahiq belum tentu sampai dan dapat memanfaatkannya.

4. Para pengelola zakat masih beranggapan bahwa pengelola zakat hanya merupakan kegiatan ritual, oleh karena itu, dilakukan hanya sekedar melaksanakan kewajiban agama atas dasar keikhlasan saja. ${ }^{49}$

Mendasar pada pemahaman masyarakat di atas, maka selayaknya model dan tata cara pengelolaan zakat harusnya dirubah. Hal yang sangat mendasar dalam pengelolaan ini adalah meyakinkan masyarakat bahwa zakat telah dikelola sangat baik oleh para amil atau pengelola badan zakat. Masyarakat dapat diyakinkan bahwa harta zakat mereka benar-benar sampai kepada para pihak yang menerimanya. Karena itu, berkaitan dengan hal ini, transparansi dalam pengelolaan sangat dibutuhkan, hal ini disebabkan pada umumnya keyakinan akan bertambah manakala dibuktikan dengan hal-hal yang riil dahulu. Disamping itu, menunjukkan kepada masyarakat bahwa amil dan badan zakat telah melakukan pengelolaan zakat dengan baik dan amanah. ${ }^{50}$

Untuk memberikkan kepercayaan kepada masyarakat, BAZNAS telah memberi penjelasan tentang kompetensi yang harus dimiliki dan dikembangkan agar mendapat kepercayaan dari masyarakat dengan mensosialisasaikan misi-mivi BAZNAS, antara lain:51

1. Mengkoordinasikan BAZNAS provinsi, BAZNAS kabupaten/kota, dan LAZ dalam mencapai target-target nasional.

2. Mengoptimalkan secara terukur pengumpulan zakat nasional

3. Mengoptimalkan pendistribusian dan pendayagunaan zakat untuk pengentasan kemiskinan, peningkatan kesejahteraan masyarakat, dan pemoderasian kesenjangan sosial.

4. Menerapkan sistem manajemen keuangan yang transparan dan akuntabel berbasis teknologi informasi dan komunikasi terkini.

5. Menerapkan sistem pelayanan prima kepada seluruh pemangku kepentingan zakat nasional.

6. Menggerakkan dakwah Islam untuk kebangkitan zakat nasional melalui sinergi ummat.

7. Terlibat aktif dan memimpin gerakan zakat dunia.

8. Mengarusutamakan zakat sebagai instrumen pembangunan menuju masyarakat yang adil dan makmur, baldatun thayyibatun wa rabbun ghafuur.

9. Mengembangkan kompetensi amil zakat yang unggul dan menjadi rujukan dunia. lain: ${ }^{52}$

Terkait dengan nilai-nilai BAZNAS yang di tawarkan kepada para muzakki antara

1). Visioner,2) Optimis, 3) Jujur, 4), Sabar), 5), Amanah, 6), Keteladanan, 7), Professional, 8), Perbaikan Berkelanjutan, 9), Entreprenurial, 10) Transformasional.

Dengan visi-misi, nilai-nilai yang ditawarkan BAZNAS diharapkan bisa memicu ghirah (keinginan) masyarakat untuk mempercayakan zakatnya kepada lembaga-lembaga amil yang ada, khususnya BAZNAS. Dan beberapa lembaga lain di bawah permerintah seperti BAZDA yang ada di beberapa daerah. Atau bisa di salurkan melalui Lembaga Amil Zakat (LAZ) di bawah naungan Organisasi Masyrakat, misalnya LAZISNU, LAZISMU, Dompet Dhu'afa dll. Pengelolaan zakat berbasis manajemen dapat dilakukan dengan

\footnotetext{
${ }^{49}$ Ibid., 18

${ }^{50}$ Ibid., 23

${ }^{51}$ http://baznas.go.id/profil

${ }^{52} \mathrm{http} / / /$ baznas.go.id/profil
} 
asumsi dasar bahwa semua aktivitas yang terkait dengan zakat dilakukan secara professional. Pengelolaan zakat secara professional, perlu dilakukan dengan saling keterkaitan antara berbagai aktivitas yang terkait dengan zakat. Dalam hal ini, keterkaitan antara sosialisasi, pengumpulan, pendistribusian atau pendayagunaan, serta pengawasan. Semua kegiatan itu harus dilakukan menjadi sebuah kegiatan secara utuh, tidak dilaksanakan secara parsial atu bergerak sendiri-sendiri.

Dalam membangun manajemen dalam mengelola zakat dapat menggunakan teori James Stoner. Model manajemen tersebut meliputi proses perencanaan (planning), pengorganisasian (organizing), pengarahan (actuating) dan pengawasan (controlling). Keempat model Stoner ini dapat diterapkan dalam setiap aktivitas pengelolaan zakat dengan konsep sosialisasi, pengumpulan, pendayaguaan dan pengawasan.

\section{Ruang Lingkup Pengelolaan Zakat berbasis Manajemen}

Keempat konsep manajemen di atas, yaitu perencanaan, pengorganisasian, pengarahan, dan pengontrolan, dapat digunakan dalam pengeloaan zakat. Masingmasing dapat dijabarkan sebagai berikut:

a. Perencanaan (Planning).

Dalam mengelola zakat diperlukan perumusan dan perencanaan tentang apa saja yang akan dikerjakan oleh pengelola badan zakat, yaitu amil zakat, bagaimana pelaksanaan pengelola zakat yang baik, kapan mulai dilaksanakan, dimana tempat pelaksanaannya, siapa yang melaksanakan, dan perencanaan-perencanaan lain. Pengelola zakat (amil) pada suatu badan pengelolaan zakat dapat merencakan zakat dengan mempertimbangkan hal-hal; perencanaan sosialisasi ke masyarakat muslim, perencanaan pengumpulan zakat pada hari-hari yang ditentukan, perencaan pendayagunaan zakat, dan perencanaan distribusi zakat kepada para mustahiq, serta perencanaan pengawasan zakat sehingga bisa akses dengan baik oleh muzakki, mustahiq dan stakeholders.

b. Pengorganisasian (Organizing).

Dalam pengelolaan zakat, pengorganisasian sangat diperlukan. Hal ini terkait dengan koordinasi pemanfaatan sumberdaya manusia dan sumberdaya zakat yang telah dikumpulkan oleh lembaga zakat. Pengorganiasian dalam pengelolaan zakat bertujuan, agar zakat dapat dikelola dengan kredibel dan efektif serta tepat sasaran untuk mencapai tujuan. Pengorganisasian yang baik adalah dilakukan oleh sumberdaya manusia yang mempunyai kapasitas dalam mengorganisasi dengan efektif dan efesien.

3. Penggerakan (actuating).

Dalam pengeloaan zakat, penggerakan (actuating) memiliki peran stategis dalam memperdayakan kemampuan sumberdaya amil (pengelola) zakat. Sebab, dalam pengelolaan zakat pengerakan memiliki fungsi sebagai motivasi, sehingga sumber daya amil zakat memiliki disiplin kerja tinggi. Untuk menggerakkan dan memotivasi karyawan, pimpinan amil zakat harus mengetahui motif dan motivasi yang diinginkan oleh para pengurus amil zakat. Hal yang harus dipahami bahwa orang mau bekerja karena merkea ingin memnuhi kebutuhannya, baik kebutuhan yang didasari maupun kebutuhan yang tidak didasari, berbentuk materi atau non-materi, kebutuhan fisik maupun kebutuhan rohaniah.

4. Pengawasan (controlling).

Dalam pengelolaan zakat, kewajiban yang harus diharus lakukan setelah tahapan-tahapan manajemen adalah pengawasan. Proses control merupakan 
kewajiban yang terus menerus harus dilakukan untuk pengecekan terhadap jalannya perencanaan dalam organisasi termasuk dalam pengelolaan zakat. Kesalahan dalam perencanaan, pengorganisasian, dan pengawasan dapat diteliti dengan cara mengontrol dan mengawasi setiap kegiatan yang dilakukan dalam pengelolaan zakat.

\section{Penutup}

Konsep zakat dalam Islam adalah kadar sebagian harta dari harta yang memenuhi syarat minimal (nishab) dan rentang waku satu tahun (haul) yang menjadi hak dan diberikan kepada mustahiq (penerima zakat). Manajemen pengelolaan zakat yang dirasa penting untuk kesejahteraan umat Islam, maka zakat harus dikelola dengan baik agas dapat mendapat kepercayaan dari masyarakat. Dalam mengelola zakat bisa melalui manajemen. Pengelolaan zakat berbasis manajemen dapat dilakukan dengan asumsi dasar bahwa semua aktivitas yang terkait dengan zakat dilakukan secara professional. Pengelolaan zakat secara professional, perlu dilakukan dengan saling keterkaitan antara berbagai aktivitas yang terkait dengan zakat. Membangun manajemen dalam mengelola zakat dengan menggunakan teori James Stoner. Model manajemen tersebut meliputi proses perencanaan (planning), pengorganisasian (organizing), pengarahan (actuating) dan pengawasan (controlling). Keempat model Stoner ini dapat diterapkan dalam setiap aktivitas pengelolaan zakat dengan konsep sosialisasi, pengumpulan, pendayaguaan dan pengawasan.

\section{Daftar Pustaka}

Al-Qardhawi, Yusuf, Figh al-Zakat: Dirasah Muqaranah li Abkamiha wa Falsafatiha fi Dhau' alQur'an wa al-Sunnah, (Beirut: Muassasah al-Risalah, 1997). >>> > > > > > > > >................................ Hukum Zakat, E-Book Hukum Zakat: Studi Komparatif Mengenai Status dan Filsafat Zakat Berdasarkan Qur'an dan Hadits, Jakarta: Litera Antar Nusa dan Mizan, Cetakan Keempat 1996).

Spektrum Zakat: Dalam Membangun Ekonomi Kerakyatan, terj. Sari Nurulita, (Jakarta: Zikrul Media Intelektual, 2005).

Al-Zuhayly, Wahbah, Fiqh al-Islamiy wa Adillatub Vol:2 , (Damaskus: Darul Fikr, 1984).

Arifin, Gus, Dalil-Dalil dan Keutamaan Zakat, Infak dan Sedekah, Jakarta: PT. Elex Media Komputindo, 2011.

Ash-Shiddieqy, Pedoman Zakat, Semarang: Pustaka Rizki Putra, 1999.

Depag RI, Standarisasi Manajemen Zakat, Jakarta: DirektoratJenderal Bimbingan

Masyarakat Islam DirektoratPemberdayaan Zakat, 2007.

Hafidhuddin, Didin, Panduan Praktis Tentang Zakat Infak dan Sedekah, Jakarta: Gema Insani Press, 1998.

Hasan, Muhammad, Manajemen Zakat: Model Pengelolaan Zakat yang Efektif, Yogyakarta:

Penerbit Idea Press, 2011.

Mustafa, Ibrahim, al-Mu'jam al-Wasith, Kairo: Dar al-Da'wah, tth.

Ridlo, Muhammad Taufiq, Zakat Profesi dan Perusahaan, Jakarta:Institut

Manajemen Zakat, 2007.

Rofiq, Ahmad, Fiqh Kontekstual: Dari Normatif ke Pemaknaan Sosial, Yogyakarta: Pustaka Pelajar, 2012) 